\title{
ANALISIS KADAR ANTOSIANIN TOTAL PADA SEDIAAN BUNGA TELANG (Clitoria ternatea) DENGAN METODE pH DIFERENSIAL MENGGUNAKAN SPEKTROFOTOMETRI VISIBLE
}

\author{
ANALYSIS OF TOTAL ANTHOCYANIN CONTENT IN TELANG FLOWERS PREPARATIONS \\ (Clitoria ternatea) WITH pH DIFFERENTIAL METHOD USING VISIBLE SPECTROPHOTOMETRY
}

\author{
Purwaniati $^{1 *}$, Ahmad Rijalul Arif ${ }^{1}$, Anne Yuliantini ${ }^{1}$ \\ ${ }^{1}$ Fakultas Farmasi Universitas Bhakti Kencana \\ ${ }^{*}$ Corresponding Author Email: purwaniati@bku.ac.id \\ DOI: http://dx.doi.org/10.47653/farm.v7i1.157
}

\begin{abstract}
ABSTRAK
Antosianin merupakan pigmen alami yang termasuk golongan flavonoid. Bunga telang mempunyai kandungan antosianin yang cukup tinggi, sehingga di masyarakat terdapat berbagai sediaan yang dibuat dari bunga telang. Antosianin dapat diekstraksi dengan melakukan penyeduhan dengan menggunakan air menyesuaikan perlakuan dari masyarakat dalam mengonsumsi sediaan bunga telang itu sendiri. penelitian ini bertujuan untuk menentukan kondisi optimum penyeduhan bunga telang segar maupun sediaannya. Kemudian, dilakukan penetapan kadar antosianin dengan menggunakan metode $\mathrm{pH}$ diferensial. Hasil dari penelitian ini menunjukan bahwa kadar antosianin ekstrak bunga telang segar lebih besar daripada sediaannya, kecuali pada sediaan yang dibuat serbuk (tea bag). Bentuk serbuk menyebabkan luas permukaan bidang sentuh lebih besar, sehingga kandungan antosianin total yang terekstraksi juga lebih besar. Kadar antosianin total yang dapat terekstraksi juga dipengaruhi oleh suhu, semakin besar suhu air yang digunakan untuk mengekstraksi, maka semakin besar kadar antosianin yang terekstraksi. Namun air yang mendidih (perebusan) menyebabkan degradasi antosianin.
\end{abstract}

Kata Kunci: Antosianin, Bunga telang, Clitoria ternatea, Kadar Antosianin Total

\section{ABSTRACT}

Anthocyanin is natural pigment include in flavonoid group. Telang flowers have a high anthocyanin content, so in the community, there are various preparations made from it. Anthocyanin can be extracted by brewing with water to adjust to the way people consume it. This research aims to determine the optimum condition of telang flowers brewing fresh or his preparations. Then, anthocyanin levels were determined using the differential $\mathrm{pH}$ method. The results of this study indicate that the anthocyanin level of telang fresh flower extract is greater than the preparation, except in tea bag preparations. The shape of the powder causes a larger surface area of the touch so that the total extracted anthocyanin content is also greater. The total extracted anthocyanin level was also influenced by temperature, the greater the temperature of the water used to extract, the greater the level of extracted anthocyanins. But boiling water causes anthocyanin degradation.

Keywords: Anthocyanin, Telang Flower, Clitoria Ternatea, Total Anthocyanin Content

\section{PENDAHULUAN}

Bunga telang (Clitoria ternatea) termasuk dari keluarga Fabaceae, atau dapat disebut juga blue pea flower. Bunga telang merupakan bunga atau tumbuhan yang biasanya merambat di hutan, pekarangan rumah, bahkan sering dapat dilihat di pinggiran sawah. Bentuk penampakan bunga telang tingginya dapat mencapai 6 meter, rantingnya halus, dan berjenis daun majemuk. Bunga ini dapat dibudidayakan dengan cara penanaman bijinya. Secara garis besarnya pigmen bunga dibedakan menjadi tiga macam yaitu flavonoids, ceratenoids, dan betalains (Tanaka Yoshikazu, 2005).

Bunga ini memiliki nama yang beraneka ragam pada setiap daerah di Indonesia, seperti di daerah Sumatera disebut bunga biru, bunga kelentit, bunga telang, di Jawa disebut kembang teleng, menteleng, di Sulawesi disebut bunga talang, bunga temen raleng, dan di Maluku disebut bisi, seyamagulele 
Bunga telang biasanya ditanam sebagai tanaman hias yang merambat dipagar, bisa juga ditemukan tumbuh liar di semak belukar pada tanah yang kering. Tanaman ini biasanya tumbuh di ketinggian $700 \mathrm{~m}$ diatas permukaan laut. (Dalimartha, 2008).

Kandungan kimia dari bunga telang antara lain adalah saponin, flavonoid, alkaloid, cooksalat, dan sulfur. Khusus untuk daunnya mengandung kaemferol, 3-glukoside, dan triterpenoid. Sedangkan bunganya mengandung delphinidine, triglucoside, dan fenol. Efek farmakologis yang dimiliki oleh tanaman bunga telang diantaranya akarnya bersifat toksik, laksatif (pencahar), diuretik, perangsang muntah, dan pembersih darah. Daunnya bersifat melancarkan peredaran darah, mencegah keguguran dan mengatur menstruasi (Hariana, 2006).

Antosianin adalah kelompok pigmen yang berwarna biru/ungu. Antosianin merupakan metabolit sekunder yang larut dalam air, memiliki banyak manfaat dan dapat ditemukan pada berbagai jenis tanaman. Antosianin dapat dijumpai pada bunga, buah-buahan dan sayur- sayuran. Salah satu manfaat antosianin adalah sebagai indikator alami $\mathrm{pH}$ (Bondre dkk., 2012).

Menurut Encyclopedia of Herbal Medicines banyak manfaat yang didapat dari bunga telang seperti: laxative (pencahar), diuretik, perangsang muntah, pembersih darah, mempercepat pematangan bisul, obat cacing dan radang mata. Senyawa kimia yang berhasil diteliti pada mahkota bunga telang mengandung 14 jenis flavonol glikosida dan 19 jenis antosianin. Antosianin memiliki kegunaan untuk pemeliharaan jaringan mata, antidiabetes, antiinflamasi, menjaga sistem imun dan mencegah agregasi trombosit (Djunarko, 2016).

Molekul antosianin tersusun dari sebuah aglikon (antosianidin) yang teresterifikasi dengan satu atau lebih glikon (gula) (Effendi, 1991). Antosianin ditemukan di vakuola sel tanaman. Senyawa ini bersifat sangat reaktif, mudah teroksidasi maupun tereduksi, serta ikatan glikosidanya mudah terhidrolisis (Hutching, 1999).<smiles>[R3]Oc1cc2c(O)cc(O)cc2[o+]c1-c1cc([R6])c(O)c([R6])c1</smiles>

Gambar 1. Struktur Antosianin

Antosianin adalah subkelas dari flavonoid yang larut dalam air yang bertanggung jawab atas warna merah, ungu dan biru pada buah, sayuran, sereal, bunga. Sehingga antosianin dapat menjadi pewarna makanan alami, selain itu, antosianin juga dipercaya sebagai antioksidan.

Struktur kimia antosianin cenderung kurang stabil dan mudah mengalami degradasi, stabilitas antosianin diantaranya dipengaruhi oleh $\mathrm{pH}$ dan temperatur. Antosianin lebih stabil pada larutan asam dibanding larutan basa. Antosianin memberikan serapan maksimum didaerah sinar tampak, yaitu pada daerah $505-535 \mathrm{~nm}$ (Harbone, 1987).

Kestabilan antosianin dipengaruhi oleh suhu. Laju kerusakan atau degradasi pada antosianin cenderung meningkat selama proses penyimpanan apabila diiringi dengan kenaikan suhu. Degradasi termal menyebabkan hilangnya warna pada antosianin yang akhirnya terjadi pencoklatan. Laju termal degradasi mengikuti kinetika orde pertama. Dan kenaikan suhu bersamaan dengan $\mathrm{pH}$ dapat menyebabkan degradasi antosianin (Rein, 2005).

Antosianin dapat mengalami perubahan warna secara reversible seiring dengan perubahan $\mathrm{pH}$. Pada $\mathrm{pH}$ sangat rendah $(\mathrm{pH} 1$ 2) antosianin berada pada bentuk oxonium yang berwarna (ion flavilium), sedangkan pada $\mathrm{pH}$ 4-5 akan terbentuk senyawa hemiketal yang tidak berwarna. Perubahan struktur dan warna tersebut menimbulkan perubahan absorbansi pada pola spektra yang muncul jika 
dibaca dengan spektrofotometer visibel (Wrolstad dan Giusti, 2001).

Metode ekstraksi antosianin yang pernah dilakukan sebelumnya yaitu menggunakan cara sederhana, yakni dengan cara maserasi dan soxhletasi. Menurut penelitian Suzery, dkk (2010), proses ekstraksi antosianin dipengaruhi oleh jumlah solvent dan temperatur. Semakin asam $\mathrm{pH}$ antosianin pada saat disimpan maka semakin baik kestabilan zat warna, penyimpanan pada $10^{\circ} \mathrm{C}$ dan tanpa terpapar cahaya lebih baik daripada penyimpanan pada suhu kamar dan terpapar cahaya. Penelitian ini berfokus pada penentuan kadar antosianin total bunga telang dalam keadaan segar, kering, dan dalam sediaan teh dengan metode ekstraksi yang lazim digunakan oleh masyarakat yang mengkonsumsi bunga telang tersebut, yaitu penyeduhan. Sehingga dapat diketahui konsentrasi rata-rata antosianin yang dikonsumsi, penelitian ini juga bertujuan untuk mengetahui pengaruh suhu terhadap kadar antosianin yang terekstraksi. Metode analisis antosianin total yang digunakan adalah metode $\mathrm{pH}$ diferensial menggunakan spektrofotometri visibel.

\section{METODE PENELITIAN Alat}

Alat-alat yang digunakan dalam penelitian ini adalah timbangan analitik, $\mathrm{pH}$ meter, tabung volumetrik, labu ukur, pipet volume, pipet tetes, mikro pipet, gelas ukur, beaker glass, corong kaca, spatel logam, batang pengaduk kaca, vial, blender, set alat spektrofotometri visibel.

\section{Bahan}

Bahan yang digunakan pada penelitian ini adalah bunga telang segar yang berasal dari bandung, sediaan bunga telang (kering dan teh), amonia, kloroform, pereaksi Mayer, serbuk $\mathrm{Mg}$, asam klorida $(\mathrm{HCl}) 2 \mathrm{~N}$ dan 0,2 N pereaksi Dragendroff, pereaksi LiebermannBurchard, Amil Alkohol, Besi(III) klorida $\left(\mathrm{FeCl}_{3}\right)$ $1 \%$, gelatin, kertas saring, kalium klorida, natrium asetat, aquadest, alumunium foil.

\section{Persiapan Sampel \\ Pembuatan Larutan Dapar pH 1,0 dan 4,5}

Larutan pH 1,0. Sekitar 0,465 gram KCl dilarutkan dengan aquades dalam tabung volumetrik $250 \mathrm{~mL}$ sampai batas. Tambahkan $\mathrm{HCl}$ sampapi $\mathrm{pH}$ mencapai 1,0 $\pm 0,1$.
Larutan pH 4,5 Sekitar 8,2 gram natrium asetat dilarutkan dengan akuades dalam tabung volumetrik $250 \mathrm{~mL}$ sampai batas. Tambahkan larutan $\mathrm{HCl}$ sampai $\mathrm{pH} \pm 4,5$.

\section{Pembuatan Ekstrak}

Metode ekstraksi pigmen antosianin dari kelopak bunga telang dilakukan dengan cara merendam 50 gram sampel dengan $300 \mathrm{~mL}$ pelarut air dengan variasi temperatur 25,50 dan $80{ }^{\circ} \mathrm{C}$ selama 15 menit. Kemudian disaring dan diambil filtratnya. Maserasi di buat triplo.

\section{Penapisan Fitokimia Uji Alkaloid}

Sebanyak 2 gram sampel dilembabkan dengan $25 \mathrm{~mL}$ ammonia $25 \% \mathrm{v} / \mathrm{v}$ dan di tambahakan $20 \mathrm{~mL}$ kloroform, lalu digerus. campuran di saring dari filtrat yang terdiri dari larutan organik digunakan untuk percobaan selanjutnya dan disebut larutan A. larutan A diekstraksi dengan asam klorida $10 \% \mathrm{v} / \mathrm{v}$ dan ekstrak yang diperoleh disebut larutan B. Larutan A diteteskan pada kertas saring, kemudian disemprot dengan pereaksi Dragendroff. Pengamatan untuk reaksi positif adalah terbentuknya warna merah atau jingga pada kertas saring. Kedalam masing-masing 5 $\mathrm{mL}$ larutan $\mathrm{B}$ dalam tabung reaksi ditambahkan beberapa tetes pereaksi Dragendorff dan pereaksi Mayer. Reaksi positif jika pada penambahan preaksi Mayer dan reaksi dragendorff akan terbentuk endapan putih atau endapan merah bata.

\section{Uji Flavonoid}

Sebanyak 1 gram sampel dalam $100 \mathrm{~mL}$ air panas didihkan selama 5 menit dan disaring. Kedalam $5 \mathrm{~mL}$ filtrat ditambahkan serbuk $\mathrm{Mg}$ dan $2 \mathrm{~mL}$ asam klorida $2 \mathrm{~N}$, kemudian dikocok dengan $10 \mathrm{~mL}$ amil alkohol. Reaksi positif ditunjukkan dengan terbentuknya warna jingga, kuning atau merah pada lapisan amil alkohol.

\section{Uji Saponin}

Sebanyak 1 gram sampel dalam $100 \mathrm{~mL}$ air panas dididihkan selama lima menit dan disaring. Filtrat yang diperoleh digunakan untuk penapisan senyawa golongan saponin, kuinon, dan tanin. Selanjutnya disebut larutan C. Sebanyak $10 \mathrm{~mL}$ larutan $\mathrm{C}$ dalam tabung reaksi dikocok secara vertikal selama 10 detik dan didiamkan. Pengamatan dilakukan terhadap busa yang terbentuk. Adanya 
saponin ditunjukkan dengan terbentuknya busa yang stabil, ketika ditambahkan satu tetes asam klorida $2 \mathrm{~N}$.

\section{Uji Kuinon}

Kedalam $5 \mathrm{~mL}$ larutan $\mathrm{C}$ ditambahkan beberapa tetes $\mathrm{NaOH} 1 \mathrm{~N}$. Terbentuknya warna merah menunjukan adanya kuinon. Namun dapat terjadi reaksi positif palsu dengan tannin. Maka pemeriksaan dilanjutkan dengan penambahan gelatin kemudian endapannya disaring dan filtratnya ditambahkan $\mathrm{NaOH} 1 \mathrm{~N}$. Bila tetap terbentuk warna merah maka menunjukkan adanya tannin.

\section{Uji Tanin}

Sebanyak $5 \mathrm{~mL}$ larutan C ditambahkan beberapa tetes $\mathrm{FeCl}_{3} 1 \%$. Jika terbentuk warna biru kehitaman menunjukkan adanya tannin. Kemudian $5 \mathrm{~mL}$ ditambahkan larutan gelatin, jika terbentuk endapan putih menunjukkan adanya tannin.

\section{Uji Steroid}

Sebanyak $500 \mathrm{mg}$ sampel ditambahkan 20 $\mathrm{mL}$ eter, maserasi selama 2 jam kemudian disaring, filtrat sebanyak delapan tetes dipindahkan kedalam cawan penguap ditambahkan beberapa tetes dipindahkan kedalam cawan penguap ditambahkan beberapa tetes pereaksi Liberman Burchard. Bila terjadi warna merah atau hijau menunjukkan adanya senyawa steroid atau triterpenoid.

\section{Penentuan Panjang Gelombang Serapan Maksimum Ekstrak}

Penentuan $\lambda$ maksimum ekstrak kelopak bunga telang dilakukan dengan metode spektrofotometri visibel. Sekitar $0,25 \mathrm{gr}$ dari masing-masing ekstrak hasil maserasi, dilarutkan dalam pelarut air hingga $5 \mathrm{~mL}$, selanjutnya absorbansi diukur pada panjang gelombang $400-800 \mathrm{~nm}$.

\section{Pengukuran dan Perhitungan Konsentrasi Antosianin Total}

Larutan sampel disiapkan dari masingmasing filtrat, setiap sampel diukur absorbansinya pada panjang gelombang serapan maksimumnya dan pada panjang gelombang $700 \mathrm{~nm}$ (sebagai koreksi absorban) dengan larutan $\mathrm{pH} \mathrm{1,0} \mathrm{dan} \mathrm{pH} 4,5$.

\section{HASIL DAN PEMBAHASAN \\ Penyiapan Sampel}

Penyiapan bahan dimulai dengan pengambilan bahan yaitu bunga telang dan sediaan yang ada di masyarakat, determinasi sampai dengan pengolahan bahan. Bunga telang segar didapat dari perkebunan Bumi Herbal Dago Bandung dan sediaan bunga telang didapat di Toko Swalayan di Bandung. Hasil determinasi dilakukan di SITH ITB Jatinangor, diperoleh informasi bahwa buga telang merupakan spesies Clitoria ternatea L.

Penelitian ini telah dilakukan analisis penetapan antosianin total dalam bunga telang segar dan sediaan bunga telang yang dikonsumsi masyarakat, baik dalam bentuk kering ataupun tea bag. proses pertama yang dilakukan adalah penyeduhan bunga telang segar dan sediaannya dengan pelarut aquades menggunakan 5 kuncup (sesuai dengan instruksi yang ada di kemasan) pada suhu ruang $(25 \mathrm{C}), 50^{\circ} \mathrm{C}$, dan $80^{\circ} \mathrm{C}$.

Dilakukan dengan berbagai suhu dikarenakan untuk mengetahui perbedaan kadar antosianin di berbagai suhu yang sering digunakan di masyarakat, suhu ruangan untuk mengetahui kadar antosianin pada keadaan biasa, suhu $50^{\circ} \mathrm{C}$ untuk mengetahui kadar antosianin pada keadaan hangat,dan pada suhu $80^{\circ} \mathrm{C}$ untuk mengetahui kadar antosianin dalam keadaan panas.

Pelarut yang digunakan adalah air, karena menyesuaikan perlakuan yang dilakukan dimasyarakat yakni menggunakan air sebagai media penyeduhan.

\section{Penapisan Fitokimia}

Penapisan fitokimia dilakukan pada simplisia untuk mengetahui golongan senyawa yang terkandung dalan bunga telang.

Tabel 1. Hasil Penapisan Bunga Telang

\begin{tabular}{cc}
\hline Golongan Senyawa & Bunga Telang \\
\hline Alkaloid & - \\
Flavonoid & + \\
Saponin & + \\
Tanin & + \\
Terpenoid & + \\
\hline Keterangan :+ mengandung senyawa metabolit sekunder tersebut
\end{tabular}

- mengandung senyawa metabolit sekunder tersebut 
Berdasarkan penapisan fitokimia ini dapat diketahui bahwa bunga telang mengandung flavonoid, saponin, tannin dan terpenoid.

\section{Penentuan Panjang Gelombang Serapan Maksimum Ekstrak}

Hasil uji spektrum tampak dengan pelarut aquades diperoleh panjang gelombang serapan maksimal $510 \mathrm{~nm}$. Pada panjang gelombang tersebut masuk dalam rentang panjang gelombang serapan maksimum teoritis antosianin yakni 505-535 nm (Harbone, 1987).

\section{Penentuan Kandungan Antosianin Total}

Kandungan antosianin total dalam sampel bunga telang segar, kering dan tea bag adalah sebagai berikut:

Tabel 2. Kadar Antosianin Dalam Sampel

\begin{tabular}{cccc}
\hline No. & Jenis Sampel & $\begin{array}{c}\text { Suhu } \\
\text { Penyeduhan }\end{array}$ & $\begin{array}{c}\% \text { Kadar Antosianin Total } \\
\mathbf{n - 3}(\mathbf{x} \text { rata-rata } \pm \text { sd })\end{array}$ \\
\hline 1. & Telang segar & Ruang & $0,1386 \pm 0,0050$ \\
& & $50^{\circ} \mathrm{C}$ & $0,1637 \pm 0,0047$ \\
& & $80^{\circ} \mathrm{C}$ & $0,1927 \pm 0,0034$ \\
\hline 2. & Telang kering 1 & Ruang & $0,1080 \pm 0,0046$ \\
& & $50^{\circ} \mathrm{C}$ & $0,1365 \pm 0,0077$ \\
& & $80^{\circ} \mathrm{C}$ & $0,1487 \pm 0,0062$ \\
\hline 3. & Telangkering 2 & Ruang & $0,1236 \pm 0,0056$ \\
& & $50^{\circ} \mathrm{C}$ & $0,1292 \pm 0,0017$ \\
& & $80^{\circ} \mathrm{C}$ & $0,1609 \pm 0,0053$ \\
\hline 4. & Tea bag & Ruang & $0,1359 \pm 0,0100$ \\
& & $50^{\circ} \mathrm{C}$ & $0,1704 \pm 0,0047$ \\
& & $80^{\circ} \mathrm{C}$ & $0,1810 \pm 0,0071$ \\
\hline
\end{tabular}

Kadar antosianin total dihitung dengan rumus:

$$
\begin{aligned}
& \% \text { Antosianin }=\frac{\text { Absorbansi } \times \text { MW x DF }}{\varepsilon \times L} \\
& \text { Absorbansi }=\left(A_{510}-A_{700}\right) \mathrm{pH} 1,0-\left(A_{510} n m-A_{700}\right. \\
& n m) p H 4,5
\end{aligned}
$$

$$
\begin{aligned}
& \text { Keterangan: } \\
& \varepsilon=\text { absorptivitas molar Sianidin-3-glukosida }=26900 \\
& \text { L/(mol.cm }) \\
& \mathrm{L}=\text { lebar kuvet }=1 \mathrm{~cm} \\
& \mathrm{MW}=\text { berat molekul Sianidin-3-glukosida }(449,2 \mathrm{~g} / \mathrm{mol}) \\
& \text { DF = Faktor Kelarutan }
\end{aligned}
$$

Dari tabel 2 diatas dapat diketahui bahwa kandungan antosianin total dalam ekstrak berbanding lurus dengan suhu pelarutnya. Sehingga dapat dinyatakan bahwa menyeduh bunga telang dengan air panas (sekitar $80^{\circ} \mathrm{C}$ ) akan memberikan hasil penyarian antosianin yang lebih baik. Namun tidak disarankan merebus bunga telang, karena sebenarnya dalam penelitian ini juga dilakukan perebusan, namun perebusan ini menyebabkan kerusakan antosianin, sehingga kadar antosianin menurun drastis.

Bunga telang segar menghasilkan antosianin total yang lebih besar dibanding antosianin kering, hal ini karena antosianin segar belum mengalami proses apapun yang berpotensi merusak antosianin, seperti pengeringan atau pemanasan. Sediaan tea bag memberikan hasil antosianin total yang lebih besar daripada bunga telang kering karena luas permukaan simplisia bunga telang yang besar menyebabkan efektivitas penyarian lebih besar.

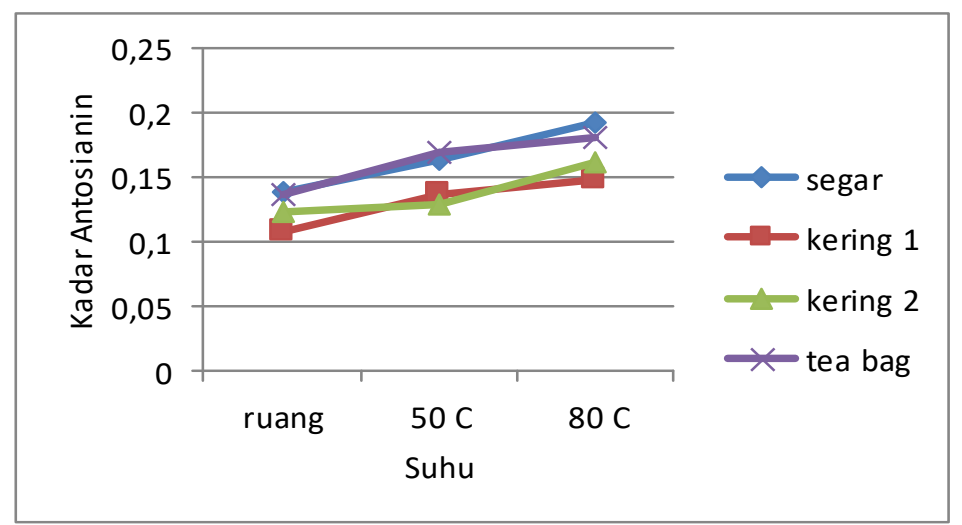

Gambar 2. Grafik Perbandingan Kadar Antosianin Total Dalam Sampel Pada Suhu Yang Berbeda 


\section{KESIMPULAN}

Kadar antosianin total yang didapat pada sediaan bunga telang segar lebih banyak dibanding bentuk sediaannya, karena bunga telang segar masih belum mengalami proses pemanasan ataupun pengawetan untuk pengonsumsian di masyarakat. Untuk sediaan bunga telang kandungan antosianin tertinggi terdapat pada sediaan tea bag karena bidang kontak dengan air lebih banyak.

Perbedaan suhu juga mempengaruhi kadar antosianin yang didapatkan, semakin tinggi suhu semakin banyak antosianin yang didapat saat penyeduhan, namun kadar antosianin akan menurun pada suhu $100^{\circ} \mathrm{C}$ karena terjadi degradasi pada antosianin.

\section{DAFTAR PUSTAKA}

Burdock, G. A. 1997. Encyclopedia of Food and Colour Additives. CRC Press. New York. pp. 1748- 1749.

Bondre, Sushma., Patil, Pallavi., Kulkarni, Amaraja., Pillai, M. M. 2012. Study on Isolation and Purification of Anthocyanins and Its Application as $\mathrm{pH}$ Indicator, International Journal of Advanced Biotechnology and Research, 3(3): 698702.

Dalimartha,S. 2008. Altas Tumbuhan Obat Indonesia Volume .5. Niaga Swadaya. Jakarta.

Djunarko, Ipang., D. Yanthre., S. Manurung, and N. Sagala. 2016. Efek Antiinflamasi Infusa Bunga Telang (Clitoriaternatea L.) dan Kombinasidengan Infusia Daun Iler (Coleus atropurpureus L. Benth) Dosis 140MG/KGBB pada Udema Telapak Kaki Mencit Betina Terinduksi Karagenin. Prosiding Rakernas dan Pertemuan IImiah Tahunan Ikatan Apoteker Indonesia.

Effendi, Wijaya. 1991 : Ekstraksi, Purifikasi dan Karakterisasi Antosianin dari Kulit Manggis (Garcinia mangostana L.). Fakultas
Teknologi Pertanian Institut Pertanian Bogor : Bogor.

Harborne, J.B. 1987. Metode Fitokimia Penuntun Cara Moderen Menganalisis Tumbuhan. Bandung: Penerbit ITB. 6, 13.

Hariana. 2006. Tumbuhan Obat dan Khasiatnya. Jakarta: Penebar Swadaya Wisma Hijau.

Harmita. 2004. Review Artikel Petunjuk Pelaksanaan Validasi Metode dan Cara Perhitungan.Jurnal Majalah IImu Kefarmasian, Departemen Farmasi : FMIPA UI, Vol, 1, No.3.

Mulja, M. dan Suherman. 1995. Analisis Instrumental, Cetakan 1. Airlangga University Press. Surabaya.

Rein, M. 2005. Copigmentation Reactions and Color Stability of Berry Anthocyanin. University of Helsinki. Finland.

Suzery M., S Lestari., B Cahyon. 2010. Penentuan Total Antosianin Dari Kelopak Bunga Rosela (Hibiscus sabdariffa L) Dengan Metode Maserasi Dan Sokshletasi. Jurusan Kimia Fakultas MIPA Universitas Diponegoro Semarang.

Tanaka, Yoshikazu. 2006. Moleclar Characterization of The Flavonoid Biosynthesis Of Verbena Hybrida And The Functional Analysis of Verbea and Clitoria ternatea $\mathrm{F3}^{\prime} \mathrm{J}^{\prime} \mathrm{H}$ Genes in Transgenic Verbana. Plant Science Center. RIKEN (The Institute of Physical and Chemical Research). Yokohama. Japan.

Tjitrosoepomo, Gembong. 1985. Morfologi Tumbuhan. Yogyakarta:Gajah Mada University Press.

Van Steenis, C.G.G.J. 2003. Flora. Pradaya Paramitha. Jakarta.

Wrolstad, Ronald E., Giusti, M. Monica. 2001. Characterization and Measurement of Anthocyanins by UV-Vis Sepctroscopy. Current Protocols in Food Analytical Chemistry, F1.2.1-F1.2.13. 